\title{
Erectile Dysfunction (ED) within Hospital Facilities in Cotonou
}

\author{
Natchagandé Gilles, Avakoudjo Dedjinin Georges Josué, Yevi Inès Dodji Magloire, \\ Agounkpé Michel Michaël, Kaka Mahamane Adama Salissou, Sossa Jean, Hodonou Detondji \\ Fred, Jacquet Djamal, Soumanou Fouad, Hounnasso Prince Pascal
}

CNHU-HKM Urology-Andrology University Clinic, Cotonou, Republique of Benin

Email: anagilas2000@yahoo.fr

How to cite this paper: Gilles, N., Josué, A.D.G., Magloire, Y.I.D., Michaël, A.M., Salissou, K.M.A., Jean, S., Fred, H.D., Djamal, J., Fouad, S. and Pascal, H.P. (2017) Erectile Dysfunction (ED) within Hospital Facilities in Cotonou. Open Journal of Urology, 7, 65-74.

https://doi.org/10.4236/oju.2017.73009

Received: January 21, 2017

Accepted: March 28, 2017

Published: March 31, 2017

Copyright $\odot 2017$ by authors and Scientific Research Publishing Inc. This work is licensed under the Creative Commons Attribution International License (CC BY 4.0).

http://creativecommons.org/licenses/by/4.0/

(c) (i) Open Access

\begin{abstract}
Introduction: Erectile dysfunction (ED) is defined as the persistent inability to achieve the necessary degree of erection for sexual activity. It is a common disease which can significantly affect the quality of life of sufferer and their partners. The purpose of this study is to give an overview of the magnitude of this medical condition in Benin society. Material and Method: It was a multicenter cross-sectional descriptive and analytical study conducted over a period of one month from $1^{\text {st }}$ to $30^{\text {th }}$ June 2015. A questionnaire was prepared for this purpose. Outcomes: The average age in this series is 48.32 with extremes ranging from 18 to 95 years. These patients were predominantly public servants. All our patients (100\% of the study population) responded to the single question of John. B. Mckinlay. The global ED prevalence was 52.6\%. The multivariate analysis helped to identify a correlation with several factors associated with ED. These factors included: age, occupation, lifestyle, etc. $41.91 \%$ of patients with ED and/or other sexual disorders declared "not at all acceptable" to continue living with these disorders. The patients benefitted from different treatments including IPDE-5 and traditional treatment in respectively $32.8 \%$ and $40.1 \%$ of cases. Conclusion: ED is a condition in its own which has an impact on the patients' quality of life. Its discovery may lead to the diagnosis of cardiovascular, hormonal or neurological diseases.
\end{abstract}

\section{Keywords}

ED, Sexual Disorder, Sexuality

\section{Introduction}

Erectile dysfunction (ED) is defined as the persistent inability to achieve the necessary degree of erection for sexual activity [1]. It is a common disease which 
can significantly affect the quality of life of sufferer and their partners [2] [3]. If for the past few years and through epidemiological studies, erectile dysfunction and its prevalence are better known than previously, no pharmaco-epidemiological research on its routine care and support has been conducted [4]. Care and support for erectile dysfunction have recently experienced major revolution leading to an increased number of patients seeking consultation [4]. Today, erectile dysfunction is recognized as a common medical condition, with its prevalence directly correlated with age and the presence of chronic diseases such as high blood pressure, stroke, dyslipidemia, diabetes and depression [5]. Sometimes, it can be symptomatic of serious pathologies [4]. Its prevalence is often under-estimated, owing to socio-cultural considerations which are still very importance in the African societies. These considerations have a significant influence on the diagnosis and treatment of this medical condition. The purpose of this study is to give an overview of the magnitude of this disease in Benin society through its incidence, social impact and therapeutic modalities.

\section{Material and Method}

\section{Framework of the study}

This study was conducted at Hubert Koutoukou Maga National Teaching Hospital (CNHU-HKM) of Cotonou (Benin), particularly in the out-patients surgery department (urology, visceral surgery, and trauma), out-patients cardiology department and internal medicine department.

\section{Period and type of study}

It was a multicenter cross-sectional descriptive and analytical study conducted over a period of one month from $1^{\text {st }}$ to $30^{\text {th }}$ June 2015 .

\section{Study population}

The study population was composed of all men aged 18 years and above, who attended any of the consultations at CNHU-HKM during the study.

\section{Sampling}

In the absence of a database pertaining to this theme, we conducted a survey on patients carrying the variables of studies. The sample size was 215 .

\section{Inclusion criteria}

-Be Benin resident, present at CNHU-HKM during the study,

-Be 18 years or above,

-And having given full consent to respond to the questionnaire.

\section{Non-inclusion criterion}

-Refusal to participate.

\section{Process of the survey}

To conduct this study, we developed a specific questionnaire made up of 65 items including the single question of John Mckinlay. It was designed on the basis of continued dynamics meant to get the respondent to open up. The questions related to the following parameters:

- General information (age, occupation, lifestyle ...),

- Reasons for consultation, 
- Co-morbidity factors,

- Assessment of the ED: It was done on the basis of the single question of John Mickinlay (linguistic translation validated): "How do you describe your current condition?"

o "Always ...",

o "Generally (not always but most of the time) ...",

o "Sometimes...",

o Or "Never ..." ... able to achieve and maintain the necessary degree of erection for sexual activities.

The validated questionnaire of John Mckinlay was used in Massachusetts Male Aging Study to classify the ED degree as slight, moderate or severe through a single question.

- Social impact of the ED on the life of the respondent: this assessment was done on the basis of the following questions,

o If you have to live the rest of your life with your current sexual disorders, will that be.

$\checkmark$ “Quite acceptable".

$\checkmark$ “Acceptable".

$\checkmark$ "Moderately acceptable".

$\checkmark$ "Not acceptable".

$\checkmark$ Does your partner suffer from the same sexual disorders?

$\checkmark$ Have you already talked to a physician about your sexual disorders? Therapeutic modalities

This study was conducted in agreement with the different departmental heads of CNHU-HKM $(n=5)$ and with urology residents $(n=17)$. These residents were well trained on the basis of a survey form established and tested in collaboration with 5 urologists for the purpose of its reliability and understanding by the respondents. During the 30-day study, the trained physicians were dispatched in the available consultation departments to administer questionnaires to patients waiting for specific consultation. Patients with proven level of education filled the questionnaire themselves, while the illiterate were supported by the trained physician.

After data collection conducted on the field, daily data check was carried out by the collection team in order to prevent duplicates and questionnaire completion errors.

The anonymous questionnaire included variables pertaining to the following:

- Socio-demographic aspects.

- Clinical aspects particularly the ED research whose severity was assessed on the basis of the response to the single question of John B. Mickanlay (sexuality assessment-based questionnaire = erection, libido, ejaculation).

- Therapeutic aspects.

- Impact of ED on the quality of life of the respondent or the couple.

Data processing and analysis

On one hand, the analysis consisted in a simple description (frequency table, 
average, standard deviation, median, graphs) of the various variables considered in the study.

On the other hand, we searched for possible statistical associations between the dependent variables and several other variables through Chi2 test, Pearson test or Fisher test according to the case or through ANOVA model. Then, a multivariate analysis was used to define the predictive models for independent variables and assess the overall impact of factors associated with the dependent variable.

Tolerable statistical significance threshold is $5 \%$. If required, the Student test and OddS ratio will be used with $95 \%$ interval.

Data editing and processing were conducted using MS Word 2007, Excel 2010 and SPSS21.

Ethical consideration

-Consent of the hospital executive director obtained.

-Consent of the departmental heads obtained.

-Compliance with respondents' anonymity.

-Informed consent of respondents obtained.

-No conflicts of interest.

\section{Outcomes}

\section{Characteristics of the population}

The number of respondents was 215 . The average age was 48.32 with 17.59 as standard deviation and 18 - 95 years as extremes.

Among the respondents, $44.6 \%$ (96/215) were at their first medical consultation, $39.1 \%(84 / 215)$ came for follow-up of medical treatment while $16.2 \%$ (35/215) came for post-surgery observation. Urology patients were predominant (127/215), followed by cardiology (31/215), visceral surgery (23/215), traumatology (19/215) and internal medicine (15/215). In $14.1 \%$ of cases, sexual disorders accounted for the only reason for consultation. They are often associated with other reasons in $35.3 \%$ of cases. Pain was the $2^{\text {nd }}$ largest reasons for consultation in $24.2 \%$ of the cases, followed by prostate pathologies in $23.7 \%$ of cases. $45.7 \%$ of patients were under long term treatment. Most of such cases often related to prostate pathology treatment (13.1\%), followed by anti-hypertensive treatment (11.6\%) and diabetes treatment (8.3\%).

\section{Prevalence and ED characteristic}

All patients (100\% of the study population) responded to the single question of John. B. Mckinlay (Table 1). Only $47.4 \%$ of them responded being "still able to achieve the necessary degree of erection for sexual intercourse" all consultation reasons included. The global ED frequency was 52.6\%. Slight ED "generally able ..." $=39$ (18.1\%), moderate ED "only capable at times ..." = 59 (27.4\%), severe ED "never able ..." = $14(7 \%)$. The overall prevalence of all sexual disorders was $63.7 \%$, or 137 patients. The comparison of patients' age based on the answer to the question of John B. Mckinlay revealed a statistically significant difference between the four groups $(\mathrm{p}=0.002)$. ED prevalence was higher among patients aged 60 years and above, giving a rate of $23.2 \%(n=50)$, respectively with slight 
$\mathrm{ED}=4.6 \%(\mathrm{n}=10)$, moderate $\mathrm{ED}=13.5 \%(\mathrm{n}=30)$, severe $\mathrm{ED}=4.6 \%(\mathrm{n}=10)$. It was followed by the age group between $39-59$ years $(n=38$ 17.67\%) with slight $\mathrm{ED}=7.9 \%$ (17 patients), moderate $\mathrm{ED}=7.4 \%(\mathrm{n}=16)$, severe $\mathrm{ED} 2.3 \%(\mathrm{n}=5)$. In the age group between 18 and 38 years ED prevalence was $11.6 \%(n=25)$, with no cases of severe DE. The ED duration and severity are highlighted in Table 2 followed by ED severity by occupation (Table 3 ).

\section{Associated factors}

The multivariate analysis helped to identify a correlation with several factors

Table 1. Overview of age, response to J. Mckinlay and ED characteristics depending on the reason for consultation.

\begin{tabular}{|c|c|c|c|c|}
\hline \multirow[t]{2}{*}{ Parameters } & \multirow{2}{*}{$\begin{array}{l}\text { Population } \\
(\mathrm{n}=215)\end{array}$} & \multicolumn{3}{|l|}{ Reasons for consultation } \\
\hline & & $1^{\text {st }}$ consultation $(n=96)$ & $\begin{array}{l}\text { Follow-up of a treatment } \\
\qquad(\mathrm{n}=84)\end{array}$ & $\begin{array}{l}\text { Observation after a surgery } \\
\qquad(\mathrm{n}=35)\end{array}$ \\
\hline Age Average \pm standard deviation & $48.32 \pm 17.59$ & $46.57 \pm 15.95$ & $52.91 \pm 292.46$ & $41.43 \pm 15.66$ \\
\hline $\begin{array}{l}\text { Response to ED question according to } \\
\text { John Mckinlay }\end{array}$ & $215(100 \%)$ & $96(44.6 \%)$ & $84(39.1 \%)$ & $35(16.3 \%)$ \\
\hline Still able & $102(47.4 \%)$ & $43(44.8 \%)$ & $41(48.8 \%)$ & $18(51.4 \%)$ \\
\hline Generally able & $39(18.1 \%)$ & $13(13.5 \%)$ & $17(20.2 \%)$ & $09(25.7 \%)$ \\
\hline Only capable at times & $59(27.4 \%)$ & $34(35.4 \%)$ & $21(25.0 \%)$ & $04(11.4 \%)$ \\
\hline Never able & $14(07.1 \%)$ & $05(06.2 \%)$ & $05(05.9 \%)$ & $04(11.4 \%)$ \\
\hline ED prevalence & $113(52.6 \%)$ & $52(55.2 \%)$ & $43(51.2 \%)$ & $17(48.5 \%)$ \\
\hline Prevalence of another sexual disorder & $103(47.9 \%)$ & $52(52.2 \%)$ & $36(42.8 \%)$ & $15(42.8 \%)$ \\
\hline $\begin{array}{l}\text { Overall prevalence of sexual disorders } \\
\qquad \text { (ED and/or other disorder) }\end{array}$ & $137(63.7 \%)$ & $66(68.7 \%)$ & $50(59.5 \%)$ & $21(60.0 \%)$ \\
\hline
\end{tabular}

Table 2. Distribution of patients based on the duration of ED severity.

\begin{tabular}{|c|c|c|c|c|c|c|}
\hline & & Duration (year) & & Pooled age & & Total \\
\hline & & & $18-38$ & $39 / 59$ & $\geq 60$ & \\
\hline \multirow[t]{5}{*}{ Slight } & Pooled duration & [1] [3] & 6 & 11 & 6 & 23 \\
\hline & & [4] [5] & 4 & 1 & 1 & 2 \\
\hline & & [6] [7] & 0 & 1 & 0 & 1 \\
\hline & & [8] [9] & 1 & 2 & 1 & 4 \\
\hline & Total & & 11 & 15 & 8 & 30 \\
\hline \multirow[t]{6}{*}{ Moderate } & pooled duration & [1] [3] & 10 & 11 & 16 & 37 \\
\hline & & [4] [5] & 2 & 4 & 7 & 9 \\
\hline & & [6] [7] & 0 & 1 & 3 & 4 \\
\hline & & [8] [9] & 1 & 1 & 2 & 4 \\
\hline & & [10] [11] & 1 & 0 & 2 & 3 \\
\hline & Total & & 14 & 19 & 30 & 57 \\
\hline \multirow[t]{4}{*}{ Severe } & pooled duration & [1] [3] & 00 & 3 & 8 & 11 \\
\hline & & [4] [5] & 00 & 1 & 4 & 3 \\
\hline & Total & & 00 & 4 & 12 & 14 \\
\hline & Total & & 25 & 38 & 50 & 113 \\
\hline
\end{tabular}


associated with ED, age, occupation, lifestyle etc ... respectively with statistically significant differences $\mathrm{p}=0.012, \mathrm{p}=0.012$ for coffee intake only. Thus, the risk of ED occurrence based on social characteristics is highlighted in Table 4.

\section{Prevalence of other sexual disorders}

Hundred and three patients or $47.9 \%$ having responded to J. B. Mckinlay questionnaire reported to have suffered from other sexual disorders other than ED. Ejaculation disorders were predominant (premature ejaculation 32.55\%), followed by pain during sexual intercourse in 13 cases (Table 5 ).

It's worth noting in Table 5 that, if some patients could develop several associated disorders, others had none.

\section{Suffering associated with sexual disorders}

Table 3. ED severity by occupation.

\begin{tabular}{|c|c|c|c|c|c|}
\hline \multirow[t]{2}{*}{ Occupation } & & \multicolumn{3}{|c|}{ ED condition } & \multirow[t]{2}{*}{ Total } \\
\hline & & Slight & Moderate & Severe & \\
\hline \multirow[t]{2}{*}{ Pupil/student } & Number & 6 & 2 & 1 & 9 \\
\hline & $\%$ included in occupation & 0.667 & 0.222 & 0.111 & 1 \\
\hline \multirow[t]{2}{*}{ Civil servant/private sector official } & Number & 17 & 22 & 2 & 41 \\
\hline & $\%$ included in occupation & 0.415 & 0,537 & 0.049 & 1 \\
\hline \multirow[t]{2}{*}{ Artisan } & Number & 7 & 15 & 2 & 24 \\
\hline & $\%$ included in occupation & 0,292 & 0.625 & 0.083 & 1 \\
\hline \multirow[t]{2}{*}{ Trader } & Number & 3 & 2 & 0 & 5 \\
\hline & $\%$ included in occupation & 0.6 & 0.4 & 0 & 1 \\
\hline \multirow[t]{2}{*}{ Other } & Number & 6 & 18 & 10 & 34 \\
\hline & $\%$ included in occupation & 0.176 & 0.529 & 0.294 & 1 \\
\hline \multirow[t]{2}{*}{ Total } & Number & 39 & 59 & 15 & 113 \\
\hline & $\%$ included in occupation & 0.345 & 0.522 & 0.133 & 1 \\
\hline
\end{tabular}

Table 4. Risk of ED occurrence based on social characteristics and the reason for consultation.

\begin{tabular}{|c|c|c|c|c|c|c|}
\hline \multirow{2}{*}{ Factors } & \multirow{2}{*}{$\begin{array}{l}\text { Bivariate analysis } \\
\text { ODDS Ratio (OR) }\end{array}$} & \multicolumn{5}{|c|}{ Multivariate analysis } \\
\hline & & IC 95\% & $\mathrm{p}$ Value & Adjusted ODD ratio (OR) & IC 95\% & $\mathrm{p}$ Value \\
\hline \multicolumn{7}{|l|}{ Social characteristics } \\
\hline Age & - & - & 0.001 & 0.522 & $0.29 ; 0.92$ & 0.027 \\
\hline Profession & - & - & 0.010 & - & - & 0.50 \\
\hline Coffee intake & 0.853 & $0.48 ; 1.49$ & 0.012 & - & - & 0.59 \\
\hline \multicolumn{7}{|l|}{ Reason for consultation } \\
\hline Prostate problem & 3.469 & $1.72 ; 6.99$ & 0.000 & 1.79 & $1.18 ; 4.56$ & 0.04 \\
\hline Sexual disorders & 4.028 & $2.18 ; 7.43$ & 0.000 & 4.11 & $1.06 ; 15.91$ & 0.04 \\
\hline Treated high BP & 2.314 & $1.28 ; 4.17$ & 0.005 & 1.81 & $1.34 ; 1.92$ & 0.04 \\
\hline Treated diabetes & 5.051 & $1.41 ; 17.99$ & 0.004 & 4.01 & $1.03 ; 15.61$ & 0.04 \\
\hline prostate pathology aftercare & $2.3 / 3$ & $1.186 ; 4.51$ & 0.004 & 1.67 & $1.77 ; 3.61$ & 0.04 \\
\hline STI & 2.110 & $1.15 ; 3.84$ & 0.014 & 1.51 & $1.75 ; 3.06$ & 0.006 \\
\hline Pelvic trauma & 2.533 & $1.32 ; 4.85$ & 0.004 & 2.54 & $1.19 ; 5.39$ & 0.015 \\
\hline
\end{tabular}


Among patients suffering from ED and/or other sexual disorders $41.91 \%$ declared "not at all acceptable" to continue living with these disorders. $13.48 \%$ suffering from ED deem it "moderately acceptable" to spend the rest of their lives with it in this condition. Furthermore, fifty-three patients or $46.9 \%$ of those with ED felt that their partners could accept their sexual status (Table 6).

\section{The first person informed about the disorders}

In this series, most patients (19.4\%) suffering from ED informed a friend first, while 21 patients or $18.5 \%$ reported to have informed a doctor (irrespective of specialties) first, a medical staff and a traditional healer in $5.3 \%$ cases respectively. However 46 patients (40.7\%) chose to remain silent.

\section{Informed therapeutic}

The patients received different treatments including IPDE-5 and traditional treatments in $32.8 \%$ and $40.1 \%$ of cases respectively. The combination of both treatments was observed in $10.9 \%$ of cases. $21.6 \%$ among patients treated with IPDE-5 declared to have had satisfaction during the treatment. Meanwhile, 7.9\% of those who underwent a traditional treatment had the same answer.

\section{Discussion}

We collected 215 questionnaires during this study. The latter is a relatively modest study compared to those already undertaken in the literature of 650 cases in the study of CHEW and et al. [6], 1740 cases in ENJEU study [7], to approximately 28,000 patients interviewed in MALE et al. study [8]. Our study

Table 5. Characteristics of other sexual disorders.

\begin{tabular}{cccc}
\hline Criteria & \multicolumn{2}{c}{$\mathrm{N}=215$} \\
\cline { 2 - 3 } & \multicolumn{2}{c}{ Proportion (\%) } & $95_{\%(\%)}$ \\
\hline Ejaculation-related problems & \multicolumn{2}{c}{103} & - \\
Premature ejaculation & \multicolumn{2}{c}{69} & $63 ; 75$ \\
Delayed ejaculation & \multicolumn{2}{c}{69} & $00 ; 04$ \\
Anejaculation & 02 & 2 & $01 ; 05$ \\
Lack of pleasure & 03 & 03 & $03 ; 09$ \\
Lack of desire & 06 & 06 & $01 ; 06$ \\
Pain during sexual intercourse & 04 & 04 & $08 ; 17$ \\
Penis curvature & 13 & 13 & $01 ; 06$ \\
\hline
\end{tabular}

Table 6. Distribution of patients based on the acceptability depending on ED severity.

\begin{tabular}{|c|c|c|c|c|c|}
\hline \multirow{2}{*}{$\begin{array}{l}\text { Idea of spending the rest of } \\
\text { life with his disorder }\end{array}$} & \multirow{2}{*}{$\begin{array}{c}\text { All disorders } \\
\text { inclusive }(n=136)\end{array}$} & \multicolumn{3}{|l|}{$\mathrm{ED}(\mathrm{n}=113)$} & \multirow{2}{*}{$\begin{array}{c}\text { Other } \\
\text { disorders } \\
(\mathrm{n}=103)\end{array}$} \\
\hline & & Slight & Moderate & Severe & \\
\hline Quite acceptable & $18(13.2 \%)$ & $06(05.3 \%)$ & $04(03.5 \%)$ & $03(02.6 \%)$ & $10(09.7 \%)$ \\
\hline Acceptable & $10(7.3 \%)$ & $05(4.4 \%)$ & $04(3.5 \%)$ & $00(00 \%)$ & $05(4.0 \%)$ \\
\hline Moderately acceptable & $30(22.1 \%)$ & $06(5.3 \%)$ & $22(19.4 \%)$ & $01(1.0 \%)$ & $21(20.3 \%)$ \\
\hline Not at all acceptable & $57(41.9 \%)$ & $18(15.9 \%)$ & $26(23.0 \%)$ & $11(9.7 \%)$ & $42(40.7 \%)$ \\
\hline Does not know & $21(15.4 \%)$ & $04(3.5 \%)$ & $03(2.6 \%)$ & $01(1.0 \%)$ & $30(29.1 \%)$ \\
\hline
\end{tabular}


population is comparable to that of N. Hicquel et al. [9] in France and Y. El Ahab and et al. [10] in Morocco who recorded respectively 160 and 189 cases and significantly higher than that of AVAKOUDJO et al. [11] who recorded 44 cases. Our patients' age varied from 18 to 95 years with an average age of 48.3 years. Some authors [8] [9] [11] recorded higher extremes than ours. This is due to the fact that lifespan is higher in their countries than in ours. The global ED frequency was $52.6 \%$ in this series. Our study was conducted over a one-month period, similarly to that of COSTA et al. [4] conducted in France. Our findings are similar to those of Y. El. Ahab and et al. [10] who recorded 52.9\%. Meanwhile, ENJEU study [7] in France recorded 67.9\%, which is significantly higher than our results, and this could be explained by the fact that ENJEU study was conducted only among patients admitted in urology consultation. Therefore these patients were already prepared for possible questions during their routine consultation. Cultural considerations in the African society where sex is still a taboo could be a limit to this study and overlook the incidence of the disease. Similarly, this study was also held in services other than urology where patients do not necessarily discuss about ED with their physician, despite the impact of this medical condition in their life. Only $18.5 \%$ declared to have informed a physician.

Several factors including age, occupation, coffee, history of prostate pathology, diabetes, hypertension, sexually transmitted infection, pelvic trauma, and sexual disorder other than ED were associated with ED occurrence with a statistically significant difference in this series. The same factors were recorded by many authors [7] [8] [9] [11] [12] as factors of developing ED. This study also revealed that ED is more severe in elderly patients than young ones. This could be related to the fact that the age group above 60 years is more exposed to chronic (cardiovascular and metabolic) and prostate diseases which are sources of ED particularly ED of organic origin. It is also the favorable age for androgenic deficiencies. Among young patients till 40s, slight ED predominance can be explained by the lack of self-control, job stress and sometimes psychological conflicts. Resurgent incidence of imitating pornographic film and futile efforts can sometimes cause feelings of worthlessness at this age which often accounts for slight ED.

Fifty three patients or $47.9 \%$ of the study population declared to have suffered from sexual disorders other than ED, and the most important was premature ejaculation. These disorders are substantial factors of ED occurrence due to their psychological impact on the sufferer. Similarly, it is worth noting the confusion often made by many patients between these disorders and ED.

The overwhelming majority of patients living with ED felt "not at all acceptable" to continue living with these disorders. The psychological motives and relational problems are important driving force for consultation with regard to some patients "ED devalue them", whereas for others "it triggers psychological problems", and finally, some patients declared that "it is a burden on their couple" [9]. Twenty one patients or $18.58 \%$ declared to have informed a physician (irrespective of the specialty) first, at the beginning of their symptomatology. Hic- 
quel et al. [9] recorded significantly higher results with $31.4 \%$ of patients with ED having consulted their referring physician for this reason. BALDWIN et al. [12] and DROUPY et al. [7] recorded respectively $22 \%$ and $58.8 \%$. The low rate of information to the physician might be explained by the fact that, a physician with no specialized training in the field could be unhelpful. Unconsciously, $\mathrm{Pa}$ tients also think that this disorder is inevitable. It is perceived as a foregone conclusion, as the result of aging, and other remote reasons are the feeling of shame "you are ashamed to talk about ED", indifference to the issue of erection ("this is not a problem" and "this is not a priority") and the preference granted to the Specialist to share their sexual problem. Furthermore, this low rate observed in this series could be explained by not only the social considerations ( $\mathrm{sex}=$ taboo subject), but also the difficulties associated with access to medical care in our countries. This justifies the high use of traditional therapeutic means and self-medication as a remedy in our study. Furthermore, in this study the assessment of the ED impact on the couple could be limited by the evaluation of the man only. This reflects the need for a study on both members of the couple simultaneously.

\section{Conclusion}

DE affects patients' quality of life; it is a symptom in its own. Its detection may lead to the diagnosis of cardiovascular, hormonal or neurological diseases. However, as confirmed by this study and the literature review, very few men suffering from ED are able to talk to their physician. There is a need to encourage behavioral change communication so that the male population could consider ED as part of the essential health-related issues.

\section{References}

[1] Lue, T.F., Guiliano, F., Montors, I.F., Rosen, R.C., Karl-Erik, A., et al. (2004) Summary of the Recommandations on Sexual Dysfunctions in Men. The Journal of Sexual Medicine, 1, 6-23. https://doi.org/10.1111/j.1743-6109.2004.10104.x

[2] Buvat, J., Ratajczyk, J. and Lemaire, A. (2002) Le problème d'érection: Une souffrance encore trop souvent cachée. Andrologie, 12, 73-83.

https://doi.org/10.1007/BF03034950

[3] Wilke, R.J., Glick, H.A., McCarron, T.J., Erder, M.H., Althof, S.E. and Linet, O.I. (1997) Quality of Life Effect of Alprostadiltheurapy for Erectly Dysfunction. J. Urol, 187, 24-28.

[4] Costa, P., Avances, C. and Wagner, L. (2003) Dysfonction érectile: Connaissances, souhaits et attitudes. Résultats d'une enquête française réalisée auprès de5.099 hommes âgés de 18 ans à 70 ans. Prog. Urol., 13, 85-91.

[5] Costa, P., Grivel, T., Giuliano, F., Pinton, P., Amar, E. and Lemaire, A. (2005) La dysfonction érectile: Un symptôme sentinelle? Prog. Urol., 15, 203-207.

[6] Chew, K.K., Earle, C.M., Stuckey, B.G., Jamrozik, K. and Keogh, E.J. (2000) Erectile Dysfunction in General Medicine Practice: Prevalence and Clinical Correlates. International Journal of Impotence Research, 12, 41-45. https://doi.org/10.1038/sj.ijir.3900457

[7] Droupy, S., Giuliano, F., Cuzin, B., Costa, P., Vicaut, E. and Levrat, F. (2009) 
Prévalence de la dysfonction érectile chez les patients consultant en urologie: L'enquête ENJEU (Enquête nationale de type 1 Jour sur la prévalence de la dysfonction Érectile chez des patients consultant en urologie). Progrès en Urologie, 19, 830-838. https://doi.org/10.1016/j.purol.2009.06.012

[8] Rosen, R.C., William, A.F., Eardley, I., Niederberger, C., Nadel, A., et al. (2004) The Multinational Men's Attitudes to Life Events and Sexuality (MALES) Study: I. Prevalence of Erectiledys Function and Related Health Concerns in the General Population. Current Medical Research and Opinion, 20, 607-617. https://doi.org/10.1185/030079904125003467

[9] Hicquel, N. (2012) Dysfonction érectile: Quels sont les facteurs influençant le recours au médecin traitant? [Thèse] Poitiers: Université de Poitiers Faculté de Médecine et Pharmacie, $48 \mathrm{p}$.

[10] El Achhab, Y., Berraho, M., Benslimane, A., Chrit, M., El Hassani, H., Lyoussi, B., et al. (2008) Diabète et dysfonction érectile au Maroc: Etude épidémiologique auprès d'une population de consultants. Rev $S$ MédOr, 14, 1090-1100.

[11] Avakoudjo, J., Paré, A., Vigan, J., Gandaho, I., Hounnasso, P., Hodonou, R., et al. (2012) La dysfonction érectile chez les patients hémodialysés au CNHU-HKM de Cotonou: Profil épidémiologique. Basic and Clinical Andrology, 22, 261-265. https://doi.org/10.1007/s12610-012-0201-4

[12] Baldwin, K., Ginsberg, P. and Harkaway, R.C. (2003) Under-Reporting of Erectile Dysfunction among Men with Unrelated Urologic Conditions. International Journal of Impotence Research, 15, 87-89. https://doi.org/10.1038/sj.ijir.3900948

\section{Submit or recommend next manuscript to SCIRP and we will provide best} service for you:

Accepting pre-submission inquiries through Email, Facebook, LinkedIn, Twitter, etc. A wide selection of journals (inclusive of 9 subjects, more than 200 journals)

Providing 24-hour high-quality service

User-friendly online submission system

Fair and swift peer-review system

Efficient typesetting and proofreading procedure

Display of the result of downloads and visits, as well as the number of cited articles

Maximum dissemination of your research work

Submit your manuscript at: http://papersubmission.scirp.org/

Or contact oju@scirp.org 